\title{
LABOR MIGRATION IN RUSSIA DURING THE CORONAVIRUS PANDEMIC
}

\author{
MIKHAIL DENISENKO, VLADIMIR MUKOMEL
}

\begin{abstract}
The introduction of quarantine measures in connection with the coronavirus pandemic was accompanied by the blocking of cross-border communications and the restriction of the activities of enterprises in most sectors of the economy. Labor migrants and members of their families staying on the territory of Russia found themselves in a difficult situation. The decline in employment, primarily in those areas where migrants work, has made foreign citizens one of the most vulnerable social groups. The first layer of issues considered in the article is associated with an assessment of the situation in which migrants have found themselves in Russia. In what types of economic activity has the decline in employment become particularly painful for migrants? What is their financial situation? To what extent are they ready to leave Russia if transport communications are restored? What are their immediate and long-term plans related to work and life in Russia? The second focus of the study is on potential migrants who were unable to enter Russia after the severance of international transport links. What is their economic situation at home? How quickly are they going to leave for Russia if restrictions on international travel are lifted? What are their short-term and long-term plans related to their stay in Russia? This article is devoted to finding answers to these questions, based on an online survey of 2,695 foreign citizens (including 1,304 migrants located in Russia and 1,391 abroad), as well as a telephone survey of 300 labor migrants in the Moscow metropolis conducted in the first half of June 2020.
\end{abstract}

Key words: labor migration, migrants, COVID-19, foreign workers, online survey, CATI, employment, migration plans.

The coronavirus epidemic has worsened the situation of labor migrants around the world (ILO 2020; OECD 2020). Russia is no exception in this regard. The introduction of quarantine measures in March 2020 suspended partially or completely the activities of many enterprises, especially in those industries where a large number of foreign workers are employed: the restaurant and hotel business, cleaning, wholesale and retail trade and, partly, construction. Like Russian citizens, some of the labor migrants lost their jobs or switched to part-time work, which led to a complete or partial loss of income. The consequence of this was the reduction in remittances to their homeland from Russia. According to the Central Bank of the Russian Federation, the volume of transfers through payment systems to CIS countries in April 2020 was 1.7 times less than in April 2019.

Mikhail Denisenko (mdenissenko@hse.ru), National Research University Higher School of Economics, RUSSIA.

Vladimir MUKomel (mukomel@mail.ru), InSTITUTE of SOCIOLOGY of FEDERAL CENTRE OF THEORETICAL AND APPLIED SOCIOLOGY OF THE RUSSIAN ACADEMY OF SCIENCES, RUSSIA.

THE INTERNET SURVEY WAS IMPLEMENTED WITH THE SUPPORT OF THE DIRECTORATE FOR EXPERT AND ANALYTICAL WORK OF THE HIGHER SCHOOL OF ECONOMICS WITHIN THE FRAMEWORK OF THE APPLIED PROJECT OF THE CENTRAL RESEARCH UNIVERSITY HIGHER SCHOOL OF ECONOMICS TZ-125: "SYSTEMATIZATION OF WAYS TO ACHIEVE NATIONAL GOALS IN ENSURING SUSTAINABLE NATURAL GROWTH IN THE POPULATION OF THE RUSSIAN FEDERATION AND INCREASING LIFE EXPECTANCY TO 78 YEARS (BY 2030, TO 80 YEARS)". THE CATI SURVEY WAS CARRIED OUT AS PART OF THE HSE CENTER FOR FINANCIAL RESEARCH PROJECT TZ-151 "ANALYSIS OF THE RISKS OF SOCIAL TENSION AND PROPOSALS FOR POLICY MEASURES AIMED AT INCREASING SOCIAL RESILIENCE".

THE ORIGINAL ARTICLE IN RUSSIAN WAS PUBLISHED IN DEMOGRAPHIC REVIEW IN 2020, 7(3), 84-107.

DOI: $10.17323 /$ DEMREVIEW.V7I3.11637 
According to estimates of the Main Directorate of Internal Affairs of the Ministry of Internal Affairs, working legally on the territory of Russia in March 2020 were more than 1 million citizens of Uzbekistan, about 500 thousand from Tajikistan and more than 350 thousand from Kyrgyzstan (the three main countries of origin of labor migrants). The termination in March of transport links with these countries made it impossible for them to return to their homeland. In total, as of April 1, 2020, according to data from the Central Data Bank for the Registration of Foreign Citizens and Stateless Persons (TsBDUIG), there were 10.2 million foreign citizens, including workers, students, tourists and others, on the territory of the Russian Federation. Of these, 4.2 million were foreigners who arrived in Russia for the purpose of "work for hire" (Florinskaya 2020: 14). Taking into account foreigners who had a residence permit and a temporary residence permit, as well as working foreign students, the total number of foreign workers in Russia was close to 5 million people.

The restrictions on the entry of foreigners and stateless persons introduced by the Government of the Russian Federation on March 18 disrupted the normal course of labor migration, in which there was a clear seasonal component. Traditionally, the number of labor migrants is minimal in January. Starting in March, as shown by the dynamics of the number of work licenses ("patents") issued to workers from Uzbekistan, Tajikistan, Ukraine, Moldova and Azerbaijan (Figure 1), their number increases rapidly along with the increasing seasonal demand for labor, the flow of migrants reaching its maximum values in April-May. But in 2020, due to the coronavirus pandemic, this did not occur. Thus, the number of first-time work licenses in May was 3.5 times lower than in January. In total, according to the Main Directorate of Migration Affairs of the Ministry of Internal Affairs of the Russian Federation, there were 1.3 million fewer foreigners registered for migration in April-June 2020 in connection with work than in the same period of 2019.

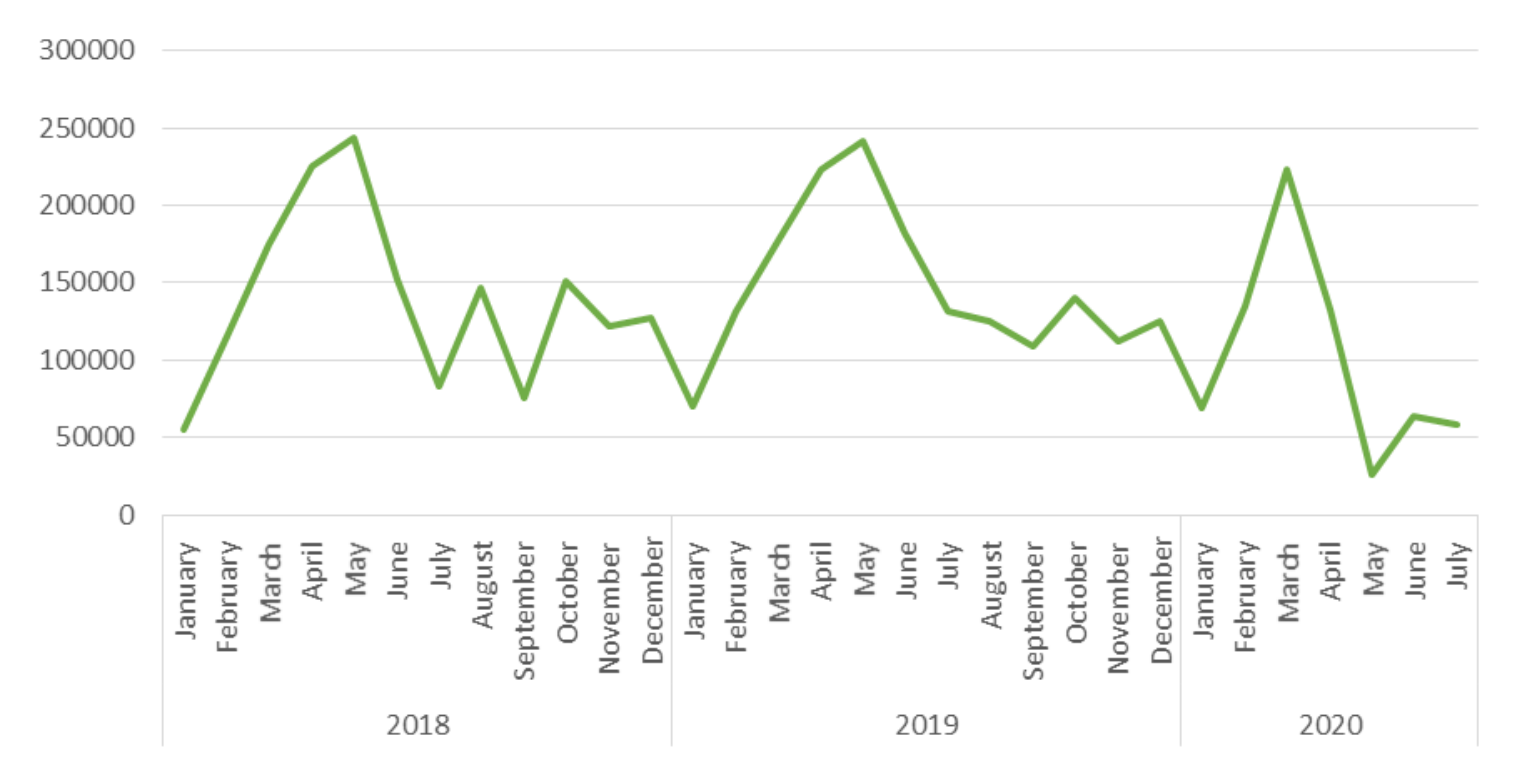

Figure 1. Number of work licenses issued in Russia from January 2018 to July 2020

Source: (Main Directorate of Migration Affairs of the Ministry of Internal Affairs of the Russian Federation 2020). 
The lack of information about the situation of foreign workers in Russia during the coronavirus pandemic has given rise to all sorts of speculation and rumors. Public opinion was agitated by mass media horror stories predicting an increase in crime among foreigners deprived of their livelihoods. A surge in alarmist sentiment took place in mid-April ${ }^{1}$. As usual, these sentiments were initiated by law enforcement officers ${ }^{2}$ and politicians ${ }^{3}$, odious personalities from the Russian Orthodox Church ${ }^{4}$ and nationalists ${ }^{5}$, as well as by "experts" who assert that "criminal sentiments among migrants are more pronounced than among Russians" (Pogrebnyak 2020) or who believe that migrants in Moscow work for a salary of 8 thousand rubles ${ }^{6}$. To them were added persons positioning themselves as representatives of migrants ${ }^{7}$ or human rights defenders.

Thus, in the generally even-handed Report of the Moscow Bureau for Human Rights (MBHR), "COVID-19: manifestations of racism, xenophobia and migration processes in a pandemic", there were unverified references to cases where migrants were not discussed at all ${ }^{8}$, or to an incident from 3 years before ${ }^{9}$. However, these cases were referred to by the media, based on the MBHR report ${ }^{10}$.

\footnotetext{
${ }^{1}$ According to the information and analytical system "Medialogia", 11\% of all publications for February-June 2020 devoted to the problems of migrants during the pandemic fell on the week from 12 to 20 April.

${ }^{2}$ See: M. Falaleev (2020). Inconvenient guests. Coronavirus may be causing an increase in crime among migrants in Russia. Rossiyskaya Gazeta, Federal issue 122 (8176), 06/07/2020. URL: https://rg.ru/2020/06/07/koronavirusmozhet-vyzvat-v-rossii-rost-prestupnosti-sredi-migrantov.html; Mikhailov Mikhail (2020). A virus for migrants. How dangerous is it for the whole society? Vmeste-RF, 06.05.2020. URL: https://vmeste-rf.tv/analytics/virus-formigrants-how-dangerous-is-it-to-society/

${ }^{3}$ See: RIA Novosti (2020). Zhirinovsky proposes to limit the return of labor migrants to Russia. 05/23/2020. URL: https://ria.ru/20200523/1571877700.html; Vakhrushev Alexey (2020). Plenipotentiary Envoy Tsukanov declares homeless people and migrants a threat during the coronavirus epidemic. Ura.ru., 13.04.2020. URL: https://ura.news/news/1052427087

${ }^{4}$ See R. Golovanov (2020). Father Dimitri Smirnov: Russia will die out. And we will be replaced by migrants. And Russians will become janitors, couriers and taxi drivers. KP, 26.04. 2020. URL:

https://www.kp.ru/daily/27122.5/4206121/.

${ }^{5}$ See: Rosbalt (2020). Russian nationalists call for the expulsion of all migrants from Central Asia before the crisis escalates into a "criminal catastrophe." 23.04. 2020. URL: https://www.rosbalt.ru/russia/2020/04/23/1840030.html ${ }^{6}$ See: E. Sokolova (2020). Coronavirus has caused an explosion of xenophobia: migrants are taking jobs from locals / Moskovsky Komsomolets, 05/20/2020; Actual Comments (2020). Powder keg: how the coronavirus has affected migrants, 05/13/2020. URL: http://actualcomment.ru/porokhovaya-bochka-kak-koronavirus-skazalsya-namigrantakh-2005131429.html

${ }^{7}$ President of the Federation of Migrants of Russia Vadim Kozhenov, who has begun to scare people with the explosive growth of crime among migrants in the first half of April (see: Steshin D. (2020). President of the Federation of Migrants Vadim Kozhenov "If unemployed migrants do not leave, the growth of crime will be explosive!" 04/14/2020. URL https://www.kp.ru/daily/27117/4197954/). A few days later, he acknowledged the absence of an increase in migrant crime, but continued to scare the average person with it (see: Govorit Moskva (2020). The Federation of Migrants has not recorded a surge in crime among foreigners in Russia, April 24, 2020. URL: https: // govoritmoskva. ru / news / 232071 /

${ }^{8}$ Lenta.ru (2020). Robber stabs Russian with knife for a bag of groceries, 05/02/2020. URL: https://m.lenta.ru/news/2020/05/02/dikost/?fbclid=IwAR3V2NekwFZ_nivMMyeZpHiryzGPBEYI0oWVCi87AXL ZzDbpij90PH2G6kI

${ }^{9} \mathrm{KP}$ (2020). In Voronezh, guest worker who robbed and severely beat a pensioner and her grandson will be tried, 30.04.2020. URL: https://www.vrn.kp.ru/online/news/3856774/?utm_source= yxnews\&utm_medium=desktop\&utm_referrer=https $\% 3 \mathrm{~A} \% 2 \mathrm{~F} \% 2 \mathrm{Fyandex} . \mathrm{ru} \% 2 \mathrm{Fnews}$

${ }^{10}$ Kompaniya (2020). In Moscow, migrants have become more likely to commit crimes, 05/12/2020. URL: https://ko.ru/news/v-moskve-migranty-stali-chashche-sovershat-prestupleniya/
} 
Of course, the voices of specialists were also heard (Abashin 2020; Poletaev 2020) ${ }^{11}$. Their position was formulated most aphoristically by D. Aleksandrov: "Migrant workers seem to me to be almost the least dangerous group of the population"12. But sane voices were drowned out by a chorus of voices screaming about migrant crime. Denials by the Moscow and federal authorities of the growth of migrant crime also had no significant impact on the media coverage of the problem ${ }^{13}$. The article titles speak for themselves ${ }^{14}$. However, the mass media ${ }^{15}$ continued to frighten the layman until the end of June with the looming increase in crimes ${ }^{16}$.

Less prominent is the topic of the prevalence of coronavirus among migrants, also presented under scary headlines. A problem does exist, but it is largely due to the fact that, according to V. Chupik, "migrants are very stigmatized, and therefore they are even ready to hide the coronavirus disease" ${ }^{17}$. The matter has not been limited to words. Already in February, representatives of "visible minorities", especially people from China and South-West Asia, in many countries of the world (USA, France, Italy, etc. - and in Russia too) faced discrimination not only in everyday life (HRW 2020).

In such circumstances, due to a lack of objective information that would make it possible to evaluate the situation in which migrants find themselves, the staff of the Institute of Sociology of the Federal Research Center of the Russian Academy of Sciences and the Higher School of Economics conducted a study focused on analyzing the employment situation of migrants, their financial situation and readiness to return home (or, for those in the country of origin, to come to Russia), their short- and long-term plans regarding work and stay in Russia.

\section{RESEARCH METHODOLOGY AND MIGRANT PROFILES}

As part of the study, in the first half of June 2020 an online survey was conducted of about 8 thousand foreign citizens, in the vast majority citizens of CIS countries. The respondents had to meet two conditions: they must not have Russian citizenship and, if they were outside of Russia,

\footnotetext{
${ }^{11}$ See also: Kommersant (2020). Stories about how migrants are going to rob non-migrants due to quarantine are a bogeyman, 04/03/2020. URL: https://www.kommersant.ru/doc/4312764

${ }^{12}$ Lenta.ru (20202). General mistrust, general fear are growing, 05/22/2020. URL: https://lenta.ru/articles/2020/05/22/migrant/

${ }^{13}$ See: Izvestia (2020). Moscow mayor's office has not seen an increase in crime among migrants during the pandemic, 05/25/2020. URL: https://iz.ru/1015171/2020-05-25/v-merii-moskvy-ne-uvideli-rosta-prestupnosti-sredimigrantov-vo-vremia-pandemii; Egorov I. (2020). Who sits on the Darknet. Rossiyskaya Gazeta (Moscow), Federal issue, 108 (8162). 05/20/2020

${ }^{14}$ Surprisingly, an article citing the words of the Deputy Secretary of the Security Council of the Russian Federation A.N. Grebenkina, "the law enforcement agencies have managed to prevent the growth of crime in the migration sphere", was published under the heading "Growth of crime among migrants recorded in Russia". See: Telegraph (2020). Growth of crime among migrants recorded in Russia, 05/21/2020. URL: https://rustelegraph.ru/news/202005-21/rost-prestupnosti-sredi-migrantov-zafiksirovali-v-rossii-90995

${ }^{15}$ See: Unclassified Materials (2020). Several million migrants travel to Russia: the first flight at the end of July, 06/29/2020. URL: https://nesekretno-net.ru/blog/43776301420/V-Rossiyu-edet-neskolko-millionov-migrantovpervyiy-reys-v-konts?utm_referrer=mirtesen.ru

${ }^{16}$ Also contributing to the hysteria was D.A. Medvedev, whose statement in June about the risk of an increase in migrant crime was widely disseminated by the mass media. See: TASS (2020). Medvedev warns of the risks of increased crime among migrants who have lost their jobs, 06/09/2020. URL: https://tass.ru/obschestvo/8687177 ${ }^{17}$ Radio Azattyk (2020). Corona crisis in Russia: consequences for labor migrants, 17.05. 2020. URL: https://rus.azattyk.org/a/30617025.html
} 
must express their intention to come to Russia in 2020. After adjusting the database (leaving out those who did not meet these requirements and those who did not complete the survey), the sample came to 2,695 respondents. 1304 respondents located on the territory of Russia and 1391 located abroad were interviewed. With a few exceptions in the wording of the questions, the questionnaire was identical for both those staying in Russia and those in the sending countries.

Along with the online survey, at the same time a similar questionnaire was used to conduct telephone interviews (Computer Assisted Telephone Interviewing, or CATI) of citizens of Kyrgyzstan, Tajikistan, Uzbekistan and Ukraine, the vast majority of them staying in Moscow and the Moscow region (300 respondents). For the telephone survey, we used data on respondents who had previously taken part in surveys by the Institute of Sociology of the Federal Research Center of the Russian Academy of Sciences. Both the online survey and the CATI survey were conducted in Russian.

The profiles of online respondents in Russia and abroad are almost identical. Men predominate among the respondents, more than a quarter of the respondents have a higher education, and one in ten has an incomplete higher education. The average age of the respondents is 37 years old (among men - 35 years old, women - 39 years old). Almost a third of the respondents identified themselves as Russian; for the majority of respondents, Russian is their mother tongue. Those who took part in the CATI survey represent a different social stratum of foreigners migrants with a lower level of qualifications and education $(17.1 \%$ of them with higher and incomplete higher education). Among them are significantly fewer Russians, with only a quarter of the respondents naming Russian as their mother tongue (Table 1).

Table 1. Main socio-demographic characteristics of migrants (online survey and CATI), $\%$ of respondents

\begin{tabular}{|c|c|c|c|}
\hline Parameters & & $\begin{array}{l}\text { Online survey (interviewed in } \\
\text { Russia and abroad) }\end{array}$ & CATI \\
\hline Sex & Male & 62.4 & 68.9 \\
\hline \multirow[t]{6}{*}{ Age, years } & Under 20 & 4.6 & 0.3 \\
\hline & $20-29$ & 27.9 & 25.0 \\
\hline & $30-39$ & 28.4 & 35.1 \\
\hline & $40-49$ & 22.5 & 27.0 \\
\hline & $50-59$ & 11.4 & 12.5 \\
\hline & 60 and older & 3.1 & 0.0 \\
\hline \multirow[t]{3}{*}{ Marital status } & Never married & 28.9 & 15.4 \\
\hline & Married (including civil and religious) & 54.7 & 71.2 \\
\hline & Widowed, divorced & 16.4 & 13.4 \\
\hline Higher education & Primary and incomplete secondary & 6.3 & 3.6 \\
\hline \multirow[t]{5}{*}{ completed } & General secondary & 25.8 & 48.5 \\
\hline & Basic vocational & 9.1 & 8.0 \\
\hline & Intermediate vocational & 22.4 & 22.1 \\
\hline & Incomplete higher & 10.3 & 4.0 \\
\hline & Higher & 26.0 & 13.1 \\
\hline Ethnicity & Russian & 29.6 & 8.2 \\
\hline Native language & Russian & 61.3 & 25.7 \\
\hline
\end{tabular}

Online polls are fraught with biases due to the specifics of the Internet audience, which is dominated by young, educated, urban respondents. In our case, the sample is also biased towards more educated migrants, which is especially evident when compared with the CATI survey, where a different contingent is represented. Other obvious biases: a higher proportion of Russians and 
those for whom Russian is their native language. At the same time, a prevalence of young contingents of foreign citizens is not observed. Probably, the share of migrants with an irregular legal status is underestimated: only $8.3 \%$ of foreigners in Russia reported not having valid documents for stay/ residence and/or employment, and another $6.1 \%$ found it difficult to answer.

Based on previous mass polling conducted by the staff of the Institute of Sociology of the Federal Scientific Research Center of the Russian Academy of Sciences for the needs of the Higher School of Economics (2011 - 8.5 thousand respondents; 2017 - 8.6 thousand respondents) and on departmental statistics of the Ministry of Internal Affairs of Russia, we can observe an underrepresentation of Central Asian migrants and an overrepresentation of Moldovans and Armenians (Figure 2).

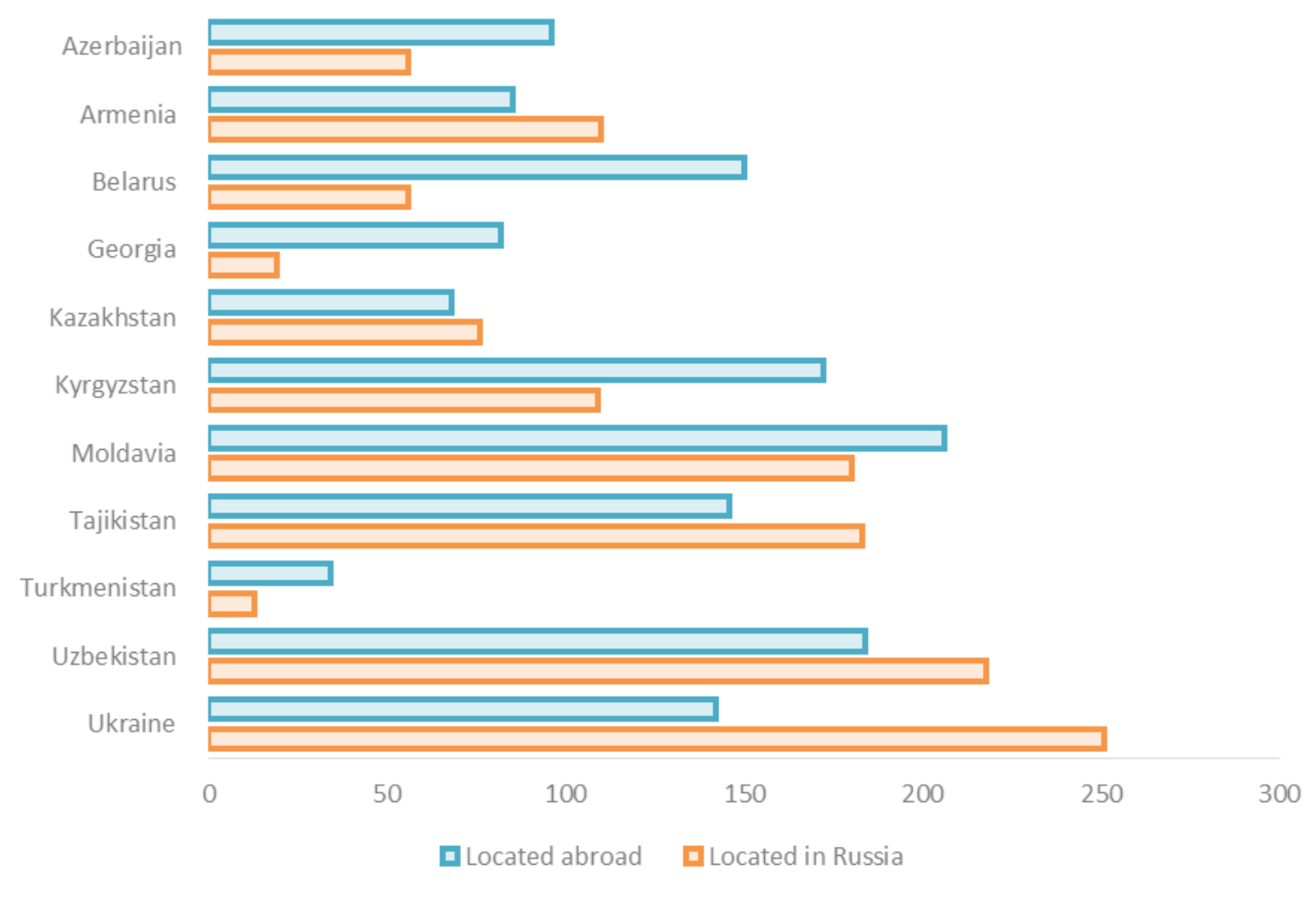

Figure 2. Distribution of respondents by country of citizenship, people

The majority of migrants in Russia $-71.1 \%$ of respondents ${ }^{18}$ - are working or are looking for work and are ready to start it. Almost the same number of respondents - 70.7\% - outside Russia intend to work after arriving in Russia. The main economic activities of those whose most recent job was in Russia (both for those now on its territory and abroad) are construction, the hotel and restaurant businesses, trade, and domestic service. Other areas of employment of the CATI survey participants: one third are employed in trade and a significant share in construction and housing and communal services (Table 2).

\footnotetext{
${ }^{18}$ Hereinafter, unless otherwise stated, the results of the online survey are given.
} 


\section{Table 2. Types of economic activities of migrants (online survey and CATI), \% of respondents}

\begin{tabular}{|c|c|c|}
\hline Types of economic activity & Online survey & CATI \\
\hline Construction & 26.8 & 17.1 \\
\hline Hotels and food service & 14.1 & 3.9 \\
\hline Wholesale and retail trade; repair of cars and motorcycles & 9.8 & 33.6 \\
\hline Domestic service & 9.2 & 4.6 \\
\hline Transport, storage & 7.5 & 8.6 \\
\hline Manufacturing industries & 6.4 & 3.6 \\
\hline $\begin{array}{l}\text { Housing and communal services, cleaning of buildings and } \\
\text { grounds }\end{array}$ & 4.5 & 15.0 \\
\hline Health care, social services & 1.8 & 1.1 \\
\hline Other personal services & 3.5 & 3.9 \\
\hline Others, no answer & 16.4 & 8.6 \\
\hline Total & 100.0 & 100.0 \\
\hline
\end{tabular}

The overwhelming majority of respondents work alone and in micro-enterprises with up to 15 employees (69.0\% according to the online survey, $64.7 \%$ according to CATI) or in small enterprises with 16 to 100 employees (19.4 and 24.8\%). These are the businesses where informal and illegal employment is most prevalent and most affected by the economic impact of the pandemic.

\section{MigRANTS IN RUSSIA}

Labor migrants and members of their families staying on the territory of Russia have found themselves in a difficult situation. The Russian authorities have taken a number of measures to prevent their social exclusion, primarily by prolonging the documents allowing migrants to stay in Russia and engage in labor activity ${ }^{19}$ The measures taken were in line with those typical for other countries, consisting in simplifying legal procedures, automatically prolonging documents necessary for migrants and facilitating their access to medical services ${ }^{20}$. However, these measures did not enjoy the unconditional support of Russians ${ }^{21}$. In general, they have not alleviated the economic situation of migrants: the decline in employment, primarily in those areas where migrants work, has made foreign citizens one of the most vulnerable social groups.

The online survey was conducted to answer the following questions: In which types of economic activity has the employment decline been particularly painful for migrants? What is their financial situation? To what extent are they ready to leave Russia if transport communications are restored? What are their immediate and long-term plans related to work and life in Russia? The survey involved foreign citizens who do not have a second (Russian) citizenship, located in

\footnotetext{
${ }^{19}$ Official Internet portal of legal information. (2020). Decree of the President of the Russian Federation dated April 18, 2020 No. 274 "On temporary measures to regulate the legal status of foreign citizens and stateless persons in the Russian Federation in connection with the threat of the further spread of a new coronavirus infection (COVID-19)." URL: http://publication.pravo.gov.ru/ Document / View / 0001202004180001

${ }^{20}$ For an overview of the practices of various countries, see: (Malakhov, Motin 2020; OECD 2020; The World Bank 2020a).

${ }^{21}$ According to one of the online polls, $3 / 4$ of the respondents of one of the business social networks spoke out against them. See: Telegram poll "BE IN THE KNOW" (2020). Russians are against Government proposal to pay migrants the minimum wage, $24 \mathrm{TM}, 04 / 26 / 2020$. https://24tm.ru/articles/40511-rossijane-protiv-predlozhenijapravitelstva-vyplachivat-migrantam-mrot-opros-telegram-bud-v-te.html
} 
78 regions of Russia, of whom 52.4\% are in Moscow and the Moscow region and $10.9 \%$ in St. Petersburg and the Leningrad region.

Among the respondents there are many students (12.3\%), as well as a number of housewives $(6.2 \%)$ and non-working pensioners (1.4\%). Another $3.5 \%$ are persons with no definite type of occupation, who did not classify themselves as belonging to a certain category and who indicated that they were neither working nor seeking work. The socio-demographic profiles of foreigners who are not present in the Russian labor market differ significantly from the profiles of those who are employed or seeking work (Table 3).

Table 3. Main socio-demographic characteristics of migrants in the labor market and other categories of migrants in Russia, \% of respondents

\begin{tabular}{|c|c|c|c|c|}
\hline Parameters & & $\begin{array}{l}\text { Working and } \\
\text { seeking work }\end{array}$ & $\begin{array}{l}\text { Other categories } \\
\text { of migrants }\end{array}$ & Total \\
\hline Sex & Male & 64.9 & 50.0 & 61.2 \\
\hline \multirow[t]{6}{*}{ Age, years } & Under 20 & 1.2 & 15.6 & 4.7 \\
\hline & $20-29$ & 27.9 & 42.7 & 31.5 \\
\hline & $30-39$ & 31.2 & 14.2 & 27.1 \\
\hline & $40-49$ & 26.1 & 14.9 & 23.4 \\
\hline & $50-59$ & 11.9 & 9.8 & 11.4 \\
\hline & 60 and older & 1.7 & 2.7 & 2.0 \\
\hline \multirow[t]{3}{*}{ Marital status } & Never married & 22.7 & 52.0 & 29.9 \\
\hline & $\begin{array}{l}\text { Married (including civil and } \\
\text { religious) }\end{array}$ & 58.6 & 40.1 & 53.6 \\
\hline & Widowed, divorced & 18.7 & 7.9 & 16.5 \\
\hline Higher education & Primary and incomplete secondary & 6.7 & 8.7 & 7.2 \\
\hline \multirow[t]{5}{*}{ completed } & General secondary & 31.2 & 16.7 & 27.7 \\
\hline & Basic vocational & 8.5 & 7.3 & 8.2 \\
\hline & Intermediate vocational & 22.2 & 23.0 & 22.4 \\
\hline & Incomplete higher & 8.5 & 23.3 & 12.2 \\
\hline & Higher & 22.8 & 21.0 & 22.4 \\
\hline Ethnicity & Russian & 22.5 & 30.3 & 24.5 \\
\hline Native language & Russian & 52.6 & 55.3 & 53.3 \\
\hline
\end{tabular}

There are many more young people among non-working migrants: over half are under 30 , mostly students. While in age groups up to 40 years men predominate, among those over 40 it is women. In fact, unemployed migrants are a conglomerate, on the one hand, of young male students (average age 22) and, on the other hand, of 40-year-old housewives and pensioners, with a few patches of retirees.

However, the majority of foreign citizens are working or looking for work. The main types of economic activities of respondents outside the Moscow metropolis are construction, hotels and restaurants, trade, domestic service and manufacturing. A somewhat different structure of employment exists in the Moscow metropolis, where the share of those employed in construction and trade is smaller, but there are more people employed in the hotel and restaurant business, domestic service and housing and communal services and who provide personal services (Table 4). 
Table 4. Types of economic activity of migrants in the Moscow metropolis and other regions of Russia in the last place of work, \% of respondents

\begin{tabular}{l|c|c}
\hline Types of economic activity & $\begin{array}{c}\text { Moscow and } \\
\text { Moscow Region }\end{array}$ & $\begin{array}{c}\text { Other regions } \\
\text { of Russia }\end{array}$ \\
\hline Construction & 25.1 & 28.4 \\
Hotels and food service & 15.9 & 13.5 \\
Wholesale and retail trade; repair of cars and motorcycles & 9.8 & 13.2 \\
Domestic service & 12.7 & 5.8 \\
Transport, storage & 7.4 & 7.7 \\
Manufacturing industries & 4.8 & 8.8 \\
Housing and communal services, cleaning of buildings and & 6.4 & 2.5 \\
grounds & 1.2 & 3.3 \\
Health care, social services & 4.2 & 2.5 \\
Other personal services & 12.5 & 14.3 \\
Others & 100.0 & 100.0 \\
Total & & \\
\hline
\end{tabular}

The work of the respondents is well paid: the average salary is 43.2 thousand rubles (the median value is 36 thousand rubles). The best paid are those working in the field of professional, scientific and technical activities, in the fields of information and communications technology, culture and leisure (79.1 thousand rubles, median 62.4 thousand rubles) and construction (49.4 thousand rubles), while the worst paid are those employed in housing and communal services (35.3 thousand rubles) and trade (35.1 thousand rubles). The earnings of less qualified workers (CATI survey) are slightly lower: the average wages in construction are 42.8 thousand rubles, in trade - 32.6 thousand rubles, in housing and communal services 30 thousand rubles.

Let us note the entrepreneurial spirit of some respondents: $3.8 \%$ of them are company owners, $3.7 \%$ are registered individual entrepreneurs, and another $7.7 \%$ are self-employed.

The overwhelming majority of those present on the Russian labor market worked last year (88.8\%). This year, $8.7 \%$ of them were unemployed from January to May. The maximum employment among those who worked in Russia this year was in February, and the peak of unemployment was in April: if we take the number of employees in January as $100 \mathrm{pp}$, then in February the percentage was 103.1, in March - 97.7, in April - 66.2, and in May - 71.2. A similar picture emerged according to the CATI survey, with an adjustment for the fact that the main type of economic activity of respondents, mainly from Central Asia, is trade: February - 103.6, March - 85.8, April - 53.5, May - 67. 2.

However, employment processes of migrants are fundamentally different in the regions and the metropolis. Moscow had the most stringent lockdown, with a rather strict regime also in the Moscow region ${ }^{22}$, while in other regions - with a few exceptions and, as a rule, later the quarantine was looser. As a result, the decrease in the migrant labor market in the megalopolis was more significant than in the regions (Figure 3).

\footnotetext{
${ }^{22}$ It should be noted that many labor migrants working in Moscow live in the Moscow region, and the restriction of transport links between Moscow and the region has reduced their opportunities to work in Moscow.
} 


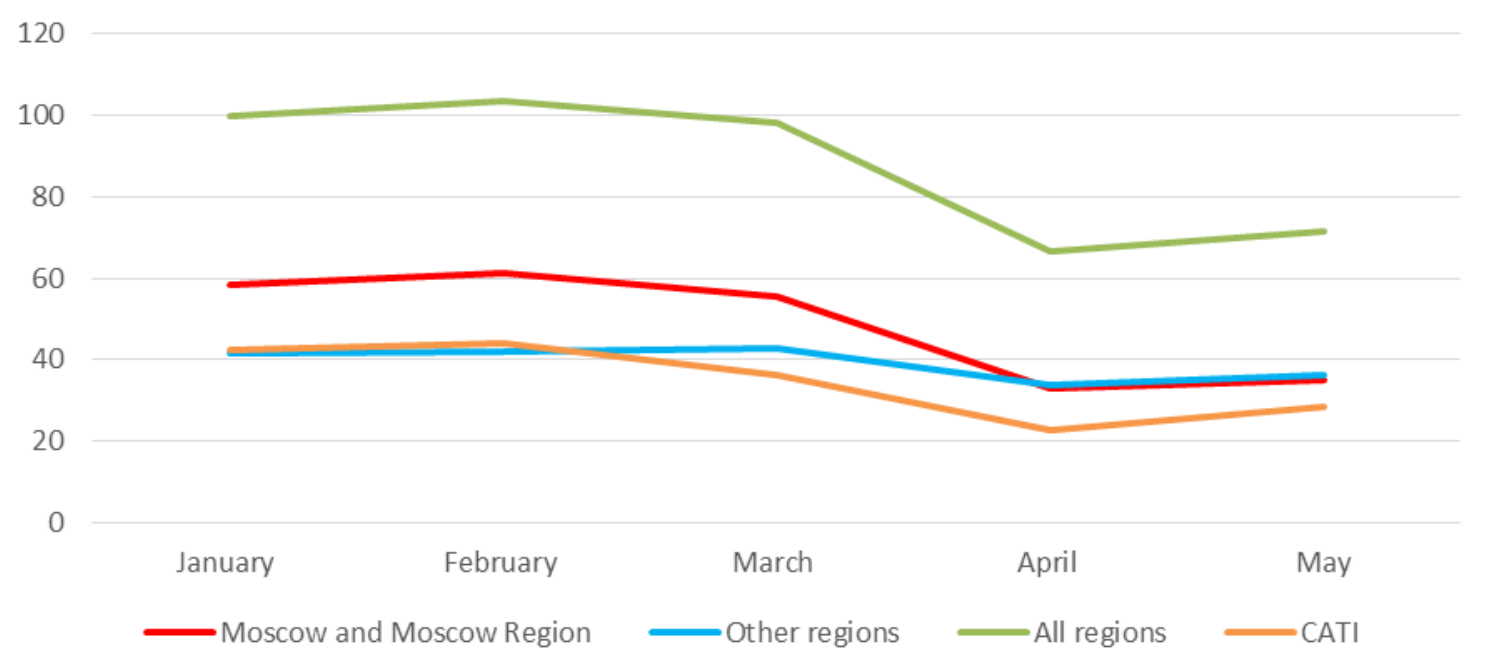

Figure 3. Dynamics of the number of employees in January-May 2020 in the Moscow metropolis and regions of Russia (all regions January $2020=100 \%$ )

Employment in the metropolis began to decline in March, while in the regions there was a continuation of the traditional seasonal growth in migrant employment. While in the megalopolis in April the number of working respondents decreased compared to March by $40.8 \%$ (and compared to February by $47.5 \%$ ), in the regions the decrease was only by $21.2 \%$. It is noteworthy that the data from the CATI survey demonstrate the same dynamics of migrant employment as the online survey in the metropolis. On the one hand, this is not surprising: $95 \%$ of CATI respondents reside in the Moscow region. On the other hand, CATI respondents are employed in the worst jobs, and this is an argument in favor of the fact that the crisis affected workers of different occupations in the same way.

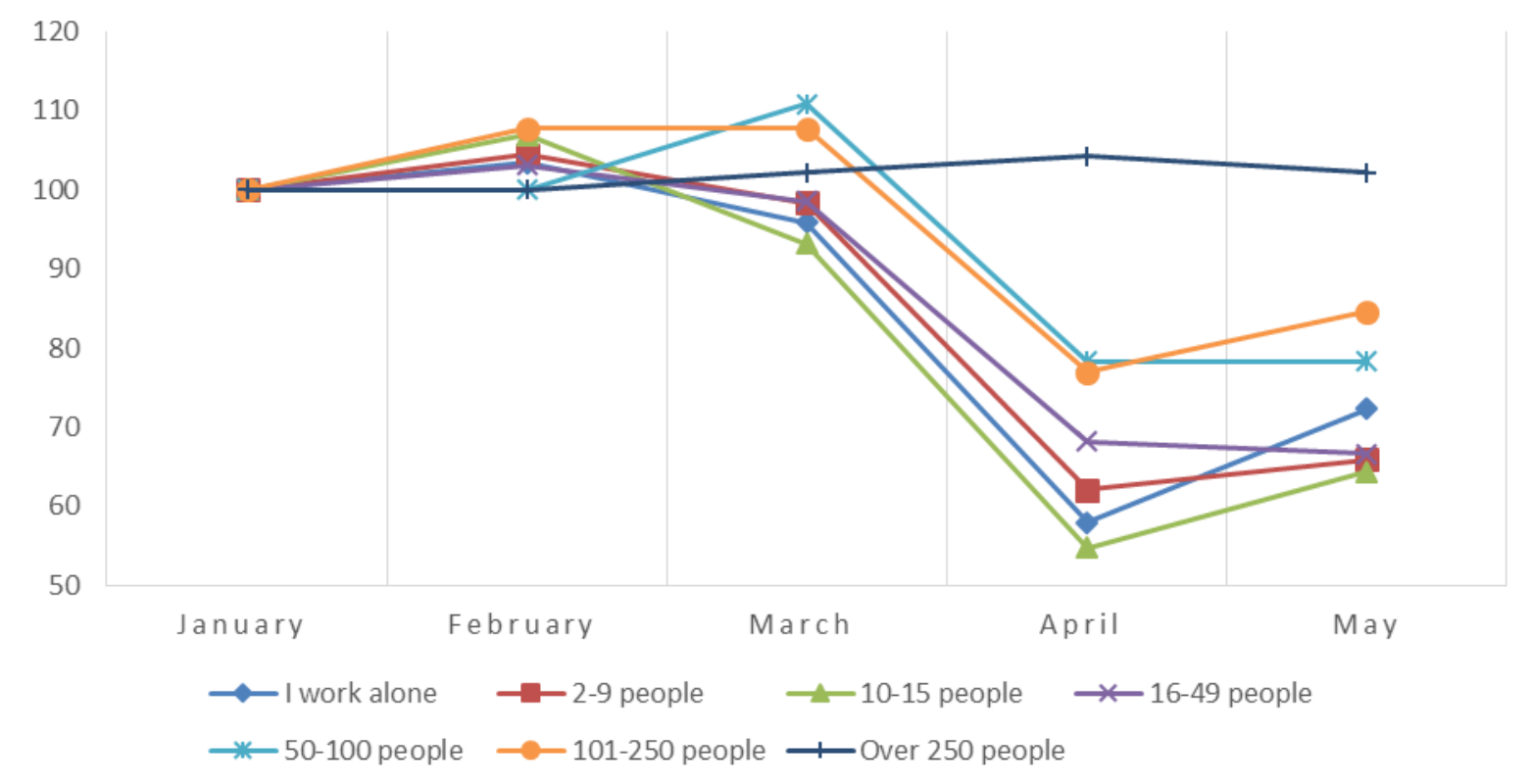

Figure 4. Change in the number of employees depending on the number of employees of an enterprise (organization) in January-May 2000, \% (January $2020=100 \%)$ 
In the spring of 2020, the greatest resilience was shown by medium and large enterprises. Hardest hit were the self-employed and those working in micro-enterprises; their numbers declined greatly in April (Figure 4).

The labor market contraction in April bypassed workers who were the backbone of the business. Employers appear to have focused on retaining the most valuable employees, getting rid above all of less experienced and skilled workers. More than half of those working in JanuaryMay 2020 (55.0\%) were those who did not lose their jobs at this time. These were the most educated (28.9\% with higher education), with a better command of the Russian language and among whom were many Russians $(32.0 \%)$. The worst-paid, most socially vulnerable groups of migrants suffered the most: those with an irregular legal status - without valid documents for stay/residence and/or employment in Russia (those who had a residence permit or a temporary residence permit lost their jobs much less often) - and the informally employed, whose labor relations were based on verbal agreements (or self-employed who had not formalized their relations with the State). While among all respondents the share of informally employed was $38.7 \%$, and among those employed in teams of up to 10 people - more than half $(51.8 \%)$ of those who worked constantly during January-May 2020 - it was significantly less - $24.2 \%$. The most vulnerable social groups of migrants, forced out of the labor market, on the one hand join the ranks of the unemployed and on the other formally improve the statistics of informal employment.

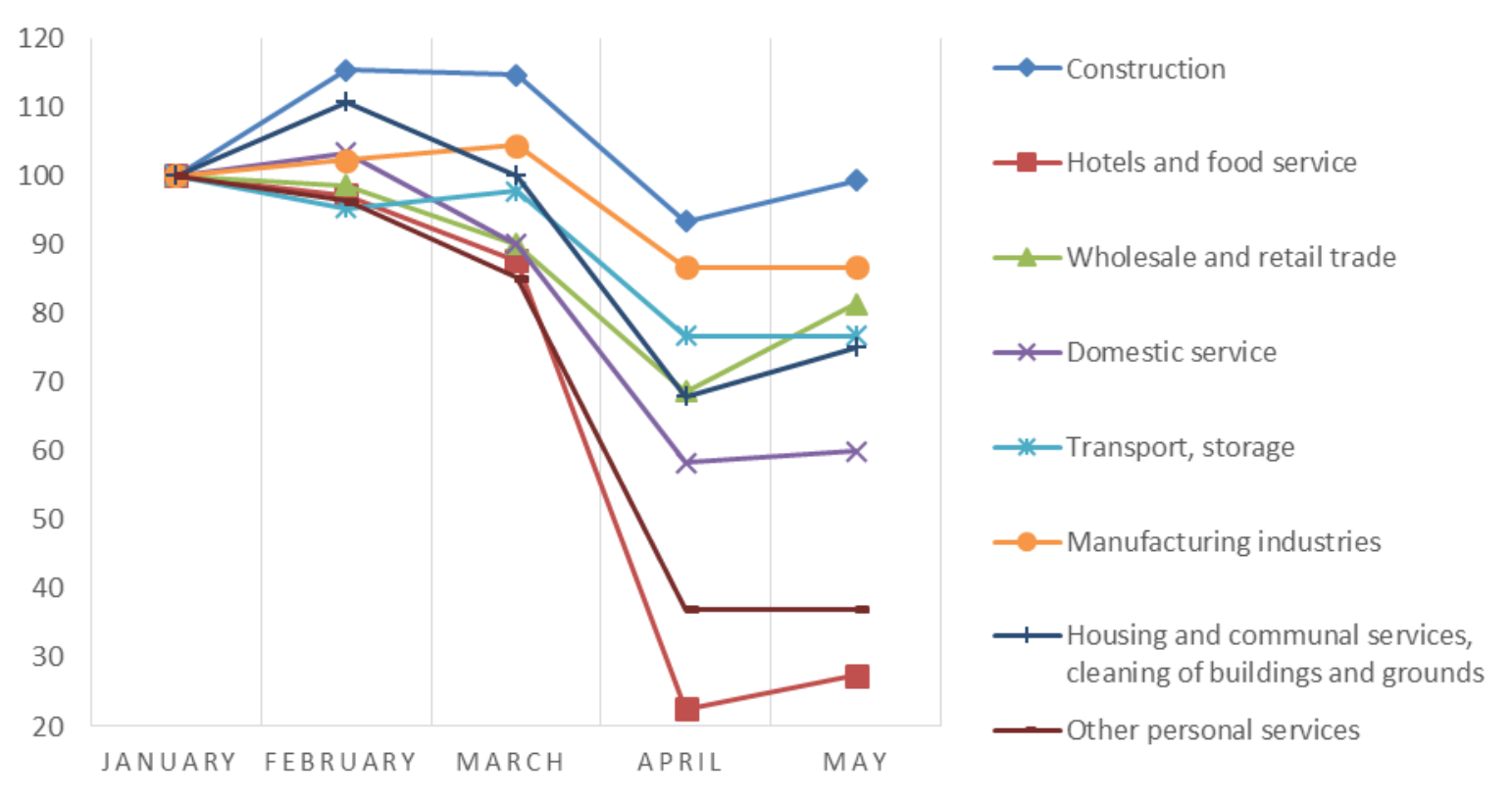

Figure 5. Change in the number of employed by the main types of economic activity of migrants in January-May 2000, \% (January $2020=100 \%)$

The crisis associated with the pandemic, as expected, hit the hotel and restaurant business hardest of all, where in the most difficult month (April) only $23.3 \%$ of those who had worked in February were still employed, followed by personal services $(38.4 \%$ of those who worked in February), domestic service $(56.4 \%)$, and trade $(69.6 \%)$, while in construction the figure was $81.0 \%$ (and in May reached its January level; Figure 5). 
However, for less skilled workers (CATI survey) the situation was more dramatic: in April, at the most difficult time, only $40 \%$ of those working at the peak of employment in February were employed in construction, trade and transport.

Citizens of Belarus, Kazakhstan, Armenia and Ukraine suffered the least from the reduction in employment. The hardest hit were citizens of Kyrgyzstan, Uzbekistan and Tajikistan: in April, among citizens of Kyrgyzstan, $47.1 \%$ of those working in February were still employed, among citizens of Uzbekistan - 52.2\%, and of Tajikistan - 69.1\% (among the latter, there were fewer people employed in the hotel and restaurant business, the sector most affected during the lockdown). A similar picture was recorded among less qualified migrants: according to the CATI survey, in April only 52.8\% of the citizens of Central Asia who worked in February were employed.

While almost $10 \%$ of Russian workers who had been employed before lockdown lost their jobs after its introduction, (Gimpelson, Kapelyushnikov 2020) ${ }^{23}$, among migrants the figure was about $40-45 \%{ }^{24}$ (in the online survey, one in three, and in the CATI poll, one in two).

It seems that, unlike Russian workers, who experienced a massive decline in wages a reaction of employers characteristic of the economic crises of the 2000s --, migrants faced massive layoffs due to the closure of businesses. Wage cuts also occurred, especially in the hardest hit sectors of the restaurant and hotel business and wholesale and retail, where employers cut primarily better-paid older workers. However, in a number of types of economic activity (domestic service, construction) wages even slightly increased (by 4.8 and $2.9 \%$ respectively in April compared to February).

The most significant reasons given for job loss were objective ones, caused by the closure of an enterprise $(31.5 \% \text { of respondents })^{25}$ or layoffs $(8.5 \%)$. It is extremely rare for workers to show initiative and leave on their own, even if they were not being paid (15.1\%). A quite common situation was that in which, due to lockdown, an organization was not working and an employee, though not paid, was helped as much as possible (with food, for example) and was still officially employed while waiting to resume his job (18.9\%). A significant part of the respondents $(26.0 \%)$ did not detail the reason for losing their jobs, vaguely indicating the pandemic. $58.1 \%$ of the respondents know relatives, friends or acquaintances who lost their jobs in Russia this year and returned to their homeland, but even more (62.8\%) reported that those who lost their jobs remained in Russia.

Job seekers find themselves in the most difficult situation: $57.3 \%$ of them do not have enough money for basic necessities. The situation is not so catastrophic for working people, housewives, students and pensioners, among whom $27.9 \%$ are in dire need. The worst situation is in Moscow, where $44.8 \%$ of foreign citizens do not have enough money for basic necessities.

\footnotetext{
${ }^{23}$ According to other estimates - one in four. See: K. Pipia (2020). From isolation to migration. Vedomosti, 03.06.2020. URL: https://www.vedomosti.ru/opinion/articles/2020/06/03/831861-izolyatsii-migratsii

${ }^{24}$ Higher estimates of the number of migrants who lost their jobs have appeared in the media, citing unknown polls.

See: Chiromon B. (2020). IOM: about 60 percent of migrants in Russia have lost income, Radio Ozodi, 03.06.2020.

URL: https://rus.ozodi.org/a/30650669.html

${ }^{25}$ The percentage of respondents facing the closure of an enterprise has been especially high in the Moscow metropolis $(37.2 \%)$, while in other regions $-21.9 \%$.
} 
According to a telephone survey, one in seven migrants in Moscow complained of having no money even for food, and one in three - no money to buy clothes.

The fear of being left without a livelihood prevails over the fear of coronavirus: the first is three times greater than the second. Covid dissidence, coupled with bravado, also occurs: $16.7 \%$ are not afraid of either one. In the CATI survey this figure is even higher - $23.4 \%$, which suggests a greater prevalence of covid dissidence among less educated migrants.

In 2020, the vast majority of respondents are planning to work, including students, housewives and retirees who have not previously been on the labor market: $78.7 \%$ are definitely planning to work, another $7.8 \%$ are considering the possibility. Only $6.5 \%$ of respondents in Russia unequivocally reject working this year, and $7.0 \%$ found it difficult to answer. Among those who plan to continue working or start working in Russia this year, $42.7 \%$ are confident that they will be able to keep their jobs, and $42.8 \%$ that they will be able to find a job (although some of them doubt that this will be done quickly). 5.9\% are not sure that they will find a job at all, and $8.7 \%$ found it difficult to answer.

Experts' assessments of the possible outflow of migrants from Russia after the resumption of interstate transport links differ. Some of them suggest a significant exodus from Russia. The possible scale of the outflow has also been given - up to a third (Abashin 2020) or even more than half of foreign citizens (Ryazantsev 2020). But this outflow, months later, will turn into a significant return movement. Supporters of a large-scale reduction in the number of labor migrants most often point to the precedents of previous economic crises, to the growing competition of foreigners in the labor market with Russian workers who have lost their jobs. More moderate assessments are based on fundamental differences between the current economic crisis and the previous ones, on the assessment of the economic situation in the main sending countries, and on the factors pushing potential migrants into the Russian labor market.

However, $78.2 \%$ of working respondents and $75.4 \%$ of those looking for work have not even considered leaving Russia in the coming months (at least until September-October); only one in ten has considered the possibility of temporarily returning to their homeland, waiting out the difficulties there and returning to Russia again (table 5). The telephone survey showed similar figures: $78.9 \%$ intend to stay in Russia for the time being, $10.0 \%$ intend to wait out the problems at home. Foreign workers relying on their employment opportunities here are reluctant to leave the Russian labor market ${ }^{26}$. The possibility of returning to their homeland, more often temporarily, is considered mainly by students, persons without specific occupations, pensioners and housewives (Table 5).

\footnotetext{
${ }^{26}$ Similar data were obtained on the intentions of Ukrainian labor migrants in Poland, $85 \%$ of whom were not planning to leave their homeland. See: Ukrinform ( $85 \%$ of employees want to stay in Poland during pandemic, 05/05/2020. URL: https://www.ukrinform.ru/rubric-society/3019588-85-rabotnikov-v-period-pandemii-hotatostatsa-v-polse.html)
} 
Table 5. Immediate plans of respondents to stay in/out of Russia, \% of respondents

\begin{tabular}{l|c|c|c|c}
\hline \multirow{2}{*}{$\begin{array}{l}\text { phat are your immediate } \\
\text { plans (until September- }\end{array}$} & \multicolumn{2}{|c|}{ Online survey } & \multicolumn{2}{c}{ CATI } \\
\cline { 2 - 5 } October 2020)"? & $\begin{array}{c}\text { Working and } \\
\text { seeking work }\end{array}$ & $\begin{array}{r}\text { Not working and } \\
\text { not seeking work }\end{array}$ & $\begin{array}{r}\text { Working and } \\
\text { seeking work }\end{array}$ & $\begin{array}{r}\text { Not working and } \\
\text { not seeking work }\end{array}$ \\
\hline $\begin{array}{l}\text { Stay in Russia } \\
\begin{array}{l}\text { Return home, wait out the } \\
\text { difficulties there and then }\end{array}\end{array} \quad 77.3$ & 62.5 & 80.9 & 67.4 \\
$\begin{array}{l}\text { come to Russia } \\
\text { Return home for good }\end{array}$ & 9.2 & 16.0 & 7.8 & 23.3 \\
$\begin{array}{l}\text { Don't know } \\
\text { Total }\end{array}$ & 3.6 & 5.1 & 5.9 & 4.7 \\
\hline
\end{tabular}

Especially important is how the situation is assessed by immigrants from Central Asian countries - the main countries of origin of migrants. But the intentions of migrants from Kyrgyzstan, Tajikistan and Uzbekistan are similar to those of migrants from other countries: to stay in Russia no matter what (Table 6). Most likely, their short-term plans are determined not so much by the current situation in Russia as by the situation at home and the assessment of all the pros and cons of a short-term and expensive departure.

Table 6. Immediate plans to stay in/out of Russia for citizens of Kyrgyzstan, Tajikistan and Uzbekistan, \% of respondents

\begin{tabular}{|c|c|c|}
\hline $\begin{array}{l}\text { "What are your immediate plans } \\
\text { (until September-October 2020)"? }\end{array}$ & Online survey & CATI \\
\hline Stay in Russia & 70.9 & 78.8 \\
\hline Return home, wait out the difficulties there and then come to Russia & 11.2 & 9.2 \\
\hline Return home for good & 4.7 & 6.5 \\
\hline No answer, hard to say & 13.1 & 5.4 \\
\hline Total & 100.0 & 100.0 \\
\hline
\end{tabular}

Considering that a significant part of the respondents have not decided on their immediate plans, it can be assumed that, taking into account the emerging economic situation, about $20 \%$ of migrants may leave Russia in the coming months (subject to the restoration of transport links and a relatively stable situation with coronavirus in Russia and the countries of origin), two thirds of whom will return to the Russian labor market in this same year.

More than half of those few who are going to leave Russia are ready to leave immediately after the restoration of transport links. But $21.5 \%$ of respondents link their readiness to leave with the coronavirus situation in Russia and at home, one in five with having money for a ticket, and one in seven with other circumstances related to family, work, etc.

The majority of those who took part in the survey are integrated into Russian society. They value their work in Russia and are afraid of losing it. A significant part of migrants have a residence permit or a temporary residence permit (24.8\% among respondents to the online survey and $30.1 \%$ according to the CATI survey) - documents that allow them to feel more free in everyday life in Russia, and especially in the labor market. The overwhelming majority of them have acceptable housing, most often a rented separate apartment, and $11.8 \%$ of the respondents or members of his/her family were homeowners, while $6.9 \%$ of the respondents had housing owned by their spouse or partner. Almost half of those who live in Russia with a spouse or partner have Russian citizenship. It is not surprising that, when asked about long-term migration plans, 
the overwhelming majority intend either to stay in Russia forever or to carry out circular migrations between Russia and the country of origin.

\section{MigRANTS AT HOME}

Over the past two decades, foreign workers have become an integral part of the Russian labor market. According to results of a federal statistical survey of the use of migrant labor, in 2019 foreigners were hired by 168 thousand Russian entrepreneurs and almost 1.4 million Russian households (Rosstat 2020a). In turn, mass labor migration from the former Soviet republics to Russia mitigates the problem of unemployment in these countries. In total, according to our estimates based on the data of the Main Directorate of Internal Affairs of the Ministry of Internal Affairs of the Russian Federation and on the statistics of the International Labor Organization, more than $16 \%$ of the labor force of Armenia and Kyrgyzstan went to work in Russia before the coronavirus crisis, while about $13 \%$ from Uzbekistan and more than $45 \%$ from Tajikistan did so. For millions of households, working in Russia has become an important source of income. For example, in 2019, the volume of migrant remittances accounted for almost $30 \%$ of the gross domestic product of Kyrgyzstan and Tajikistan, with 3/4 of all remittances to these countries coming from Russia (The World Bank 2020b).

The introduction of a self-isolation regime in Russia and the suspension of international transport links came as a tremendous shock not only for those who were in Russia, but also for those who were planning to come to it in March-June 2020. It is they, those who returned home from Russia in 2020 as well as those potential migrants who could not enter Russia after the severance of international transport links, who were the second focus of our study. What is their economic situation at home? How soon are they ready to return to Russia if the borders are opened? What are their long-term migration plans? These questions were answered by 1,391 foreign citizens outside Russia at the time of the survey. Among the respondents, $15 \%$ were citizens of Moldova, $13.2 \%$ of Uzbekistan, $12.4 \%$ of Kyrgyzstan, $10.9 \%$ of Belarus, $10.5 \%$ of Tajikistan, $10.3 \%$ of Ukraine, $6.9 \%$ of Azerbaijan, $6.1 \%$ of Armenia, $4.9 \%$ of Kazakhstan, $2.4 \%$ of Turkmenistan and $1.4 \%$ of other states.

We emphasize once again that the sample turned out to be strongly biased towards Russians and people with higher education. Thus, among the respondents, the share of those who identified themselves as Russians by ethnicity was $34.7 \%$. The second largest ethnic group were Tajiks $(9.2 \%)$, and the third, Uzbeks $(8.9 \%)$. Note that according to migration registration data, citizens of Uzbekistan and Tajikistan clearly predominate in the total number of labor migrants (almost $60 \%$ in 2019). Almost a quarter of the respondents are bilingual, that is, they named not only Russian as their native language, but another language as well. $28.7 \%$ of respondents had a higher education and $31.9 \%$ had incomplete higher and secondary vocational education. This roughly corresponds to the level of education of the Russian population aged 15 to 59 years - in 2010, $25.8 \%$ of Russians had higher education and $39 \%$ had incomplete higher or secondary vocational education. But the level of education of the respondents was higher than that of their compatriots at home. Thus, in Kyrgyzstan, about $15 \%$ of the adult population have a higher education, and in Tajikistan, about $10 \%$. 
The survey method suggested that the sample would provide a bias in favor of younger ages, but this did not happen. Almost $20 \%$ of respondents were aged 50 and over, 30\% of respondents were under 30 years old and the other half were in the middle working age range of 30 to 50 years. About $2 / 3$ of the respondents were men, which generally corresponds to the gender structure of the flow of labor migrants to Russia.

Most of the respondents (over 70\%) had previously visited Russia. Of the total number of respondents, $20.5 \%$ recently arrived from Russia and cannot return due to coronavirus restrictions, $35.8 \%$ travel to Russia from time to time, another $28.4 \%$ are planning to go to Russia for the first time. The rest are somehow connected with Russia (relatives, business trips, business, tourism, etc.). Among the respondents, of particular interest are those who came for a period of three months or more, that is, to work or study ${ }^{27}$. There were $63 \%$ of such labor and educational migrants in the sample. More than 28\% of respondents last entered Russia in 2019, about $10 \%$ - in 2018, $8 \%$ in 2020, and the remaining 54\% - before 2018. But more than half of the respondents (55\%) left Russia in $2019(27.5 \%)$ and $2020(27.5 \%)$.

As noted above, the coronavirus epidemic and the isolation regime disrupted the normal course of migration processes with their characteristic seasonal component. In January, entry to Russia is traditionally at a minimum; most labor migrants arrive in the country in March-May and return to their homeland in late autumn and early winter until January-February of the following year. According to the survey, in 2019 the number of those who returned home in March was about the same as in January, February or April, and almost 6 times less than in December. In 2020, the number of respondents who left Russia in March was 2.5 times more than the number of those who left in January.

Job loss and the coronavirus epidemic were the main push factors out of Russia. Among those who returned to their homeland in 2020, constructions workers (more than 30\%), workers in hotels and food service (11\%) and those in trade and transport $(8.2 \%$ each) predominated. But returning migrants have faced the same difficulties in their homeland as in Russia: due to the coronavirus measures taken, employment opportunities have noticeably decreased. Among those who returned home in 2020, only $40 \%$ had a job in early June, more than $50 \%$ did not have a job, and slightly less than $10 \%$ were students. Among all the respondents, $51.6 \%$ had work, $24.5 \%$ were looking for work, about $6 \%$ did not work and were not looking for work, $6.7 \%$ were students, $6 \%$ housewives and $5 \%$ pensioners.

Returning home in the context of the coronavirus epidemic and measures to combat it, of restricted international travel by all states, negatively affected the well-being of families of labor migrants in their countries of origin. The average monthly earnings of labor migrants in Russia at the beginning of 2020 was 47 thousand rubles. It was approximately the same in 2019. According

\footnotetext{
${ }^{27}$ Recall that 3 months or 90 days is a significant interval in Russian migration legislation. According to its provisions, the period of temporary stay in the Russian Federation of a foreign citizen arriving in a manner that does not require a visa cannot exceed ninety days in total during each period of one hundred and eighty days. Upon the expiration of this period, it is required to obtain permits for residence, including for employment (a work license or an application from an employer), or an application from an educational organization in which a foreign citizen is studying. See Federal Law No. 115-FZ of 25.07.2002 (as amended on 24.04.2020) "On the Legal Status of Foreign Citizens in the Russian Federation" (as amended and supplemented, entered into force on 07.07.2020). Article 5. Temporary stay of foreign citizens in the Russian Federation.
} 
to Rosstat data, this generally corresponds to the average earnings in Russia in February 2020 (Rosstat 2020b: 232). If we rely on the results of previous mass polling conducted by the staff of the Institute of Sociology of the Federal Research Center of the Russian Academy of Sciences for the needs of the Higher School of Economics (2011 - 8.5 thousand respondents; 2017 8.6 thousand respondents), then we can assume that, on average, they transferred more than $40 \%$ of their monthly income to their homeland. The cessation of money receipts from Russia has complicated the already difficult economic situation of the families of labor migrants. Only $20 \%$ of respondents said that they were not experiencing want, and another $17.5 \%$ hope to hold out without outside financial and material assistance for the next two months. The rest to one degree or another are forced to economize or resort to external support. This applies to both those who have never worked in Russia and those who only recently, in 2019 or 2020, returned from it. Particularly difficult is the situation for those respondents who were not working at the time of the survey. Material difficulties are faced by $75 \%$ of families of non-working respondents and half of families of working respondents.

For most of the respondents, the prospects for improving their financial situation are in one way or another connected with work in Russia. Among the respondents who worked or studied in Russia, 54\% are planning to come to Russia for a period of three months or more and $11.4 \%$ for a period of less than three months, while the rest had not made a decision at the time of the survey. Among the respondents heading to Russia for the first time, the share of those intending to leave for a period of three months or more is $35 \%$, for a period of less than three months $-23 \%$, and the rest were undecided. Of those surveyed who returned from Russia in 2019 and 2020, 57\% plan to return to Russia for a period of three months or more.

Almost half of potential migrants are ready to come. About $60 \%$ of those who are going to come for 3 months or more, and 55\% of those who are going to come for a short period (less than three months), answered that they will come to Russia as soon as transport links are restored or they get enough money for a ticket. The situation with coronavirus is the deciding factor for $22 \%$ of respondents intending to stay in Russia for more than three months and for $27 \%$ of those planning to stay less than three months. According to the rest of the respondents, the moment of departure for them is determined by other, above all family, circumstances. Note that among the migrants who returned from Russia in 2019 and 2020, almost 75\% are ready to return to Russia immediately after the restoration of transport links.

At the time of the survey, respondents were optimistic about getting a job in Russia. In total, $67 \%$ of respondents are confident that they will find one quickly. Among those who are going to leave immediately after the restoration of transport links, the figure is $80 \%$. Those coming to Russia for the first time are less optimistic: slightly more than half $(54 \%)$ of them are sure that work in Russia can be found quickly. But in general, almost $90 \%$ of potential migrants are sure that sooner or later they will find a job in Russia.

Thus, in the CIS countries, in the context of anti-coronavirus measures, there is a growing potential for migration to Russia. This is facilitated by the coronavirus crisis in the countries of origin of migrants, accompanied by a contraction of the labor market there and a drop in the income of a significant part of the population. The survey showed that potential migrants among respondents are "not afraid" of the coronavirus situation in Russia: one in four (25\%) is dismissive 
of the likelihood of contracting coronavirus. Most (40\%) of the respondents are afraid of the prospect of being left without means of subsistence. Migration intentions are especially strong among those who have had work or study experience in the Russian Federation, including those who were in Russia in 2019 and 2020, supported by the belief that work can be quickly found in Russia.

\section{CONCLUSION}

Unlike previous economic crises, when the number of labor migrants changed in accordance with the economic situation in Russia, during the coronavirus pandemic a fundamentally different situation has developed, in which factors pushing potential migrants from their countries of origin to the Russian labor market have become more significant. Labor migrants staying in Russia show no desire to leave, and those who had intended to wait out the difficulties in their homeland until autumn are now, due to the lack of transport links, feeling less inclined to leave Russia with each passing day. On the contrary, the "excess" number of potential labor migrants in sending countries is constantly growing. Its scale can be judged by the data of the Main Directorate of Internal Affairs of the Ministry of Internal Affairs of the Russian Federation, according to which in Russia in AprilJune 2020 almost 1.3 million fewer foreign citizens were put on migration registration for the purpose of "work" than in 2019. According to the Russian Border Service of the FSB, over the same three months of this year only 1,900 (!) foreigners crossed the border intending to work, versus 1.2 million in the same period the year before. In July-September, restrictions (with some relaxation) on international transport links with countries that are the main suppliers of labor migrants generally remained. Assuming that the state of the labor market in 2020, in the absence of a pandemic, should not have differed significantly from the previous year, over the period from April to September, due to coronavirus restrictions, more than 2.2 million labor migrants did not enter Russia. Taking into account the persistence of transport restrictions until the end of the year, this estimate will increase and exceed at least 3 million people.

Migration is of paramount importance to sending countries. First, labor migration eases pressure on the labor market in countries with rapidly growing young populations (Kyrgyzstan, Uzbekistan, Tajikistan) or countries with a "shrinking" labor market (Armenia, Moldova, Ukraine). So, in 2019, in Tajikistan $47 \%$ of the labor force participated in labor migration, in Kyrgyzstan - at least 17.5\%, in Armenia - at least 16\%, and in Uzbekistan - 14\%. Although there is a partial reorientation of the flows of labor migrants from Ukraine and Moldova to Europe, Russia still remains among the main migration destinations from these countries as well. Secondly, the countries of origin of migrants are suffering significant losses from a decrease in the inflow of remittances from labor migrants. This applies, above all, to those countries in which remittances from Russia make up a significant amount in relation to GDP (Armenia, Kyrgyzstan, Tajikistan). According to our estimates, based on data from the Bank of Russia and statistics from the World Bank, should restrictions on entry to the Russian Federation continue, the volume of migrant remittances in 2020 compared to 2019 may decrease in the CIS countries by $30 \%$, which will severely affect the welfare of these countries' populations and the stability of their financial systems and will reduce the amount of investment in their economies. 
In the context of an economic downturn and a reduction in labor demand, a decrease in the supply of foreign labor appears in Russia, as in other countries, natural and expected. However, in regions and industries with a high concentration of migrants, in industries with a strong seasonal component (agriculture, individual construction), the lack of cheap labor can complicate the process of their recovery.

Due to the coronavirus crisis in Russia, there has been a shortage of workers of low and medium qualifications in construction, trade, transport and warehousing, as well as of those with medium and high qualifications in the spheres of domestic service and personal services (types of economic activities in which the share of labor costs is maximum and where migrant labor is especially noticeable).

This was partly observed already at the bottom of the crisis: in transport and warehouses, in households and construction, the wages of the migrants interviewed increased by 10, 4.8 and $2.9 \%$, respectively, in April compared to the peak in February. Rosstat also signals this: the average salary of Russians in transportation and storage increased by $10.3 \%$ in February-April, and in construction - by $0.8 \%$. This means that, on the one hand, part of the "migrant" jobs may be occupied by Russians, both local and internal Russian migrants. On the other hand, an increase in the cost of goods and services is inevitable in those types of economic activity where migrants occupy or have occupied significant positions.

The study showed that the potential for labor migration from the CIS countries remains quite high. At the same time, the potential for resettlement and integration in Russia is also quite high and unrealized (Figure 6).

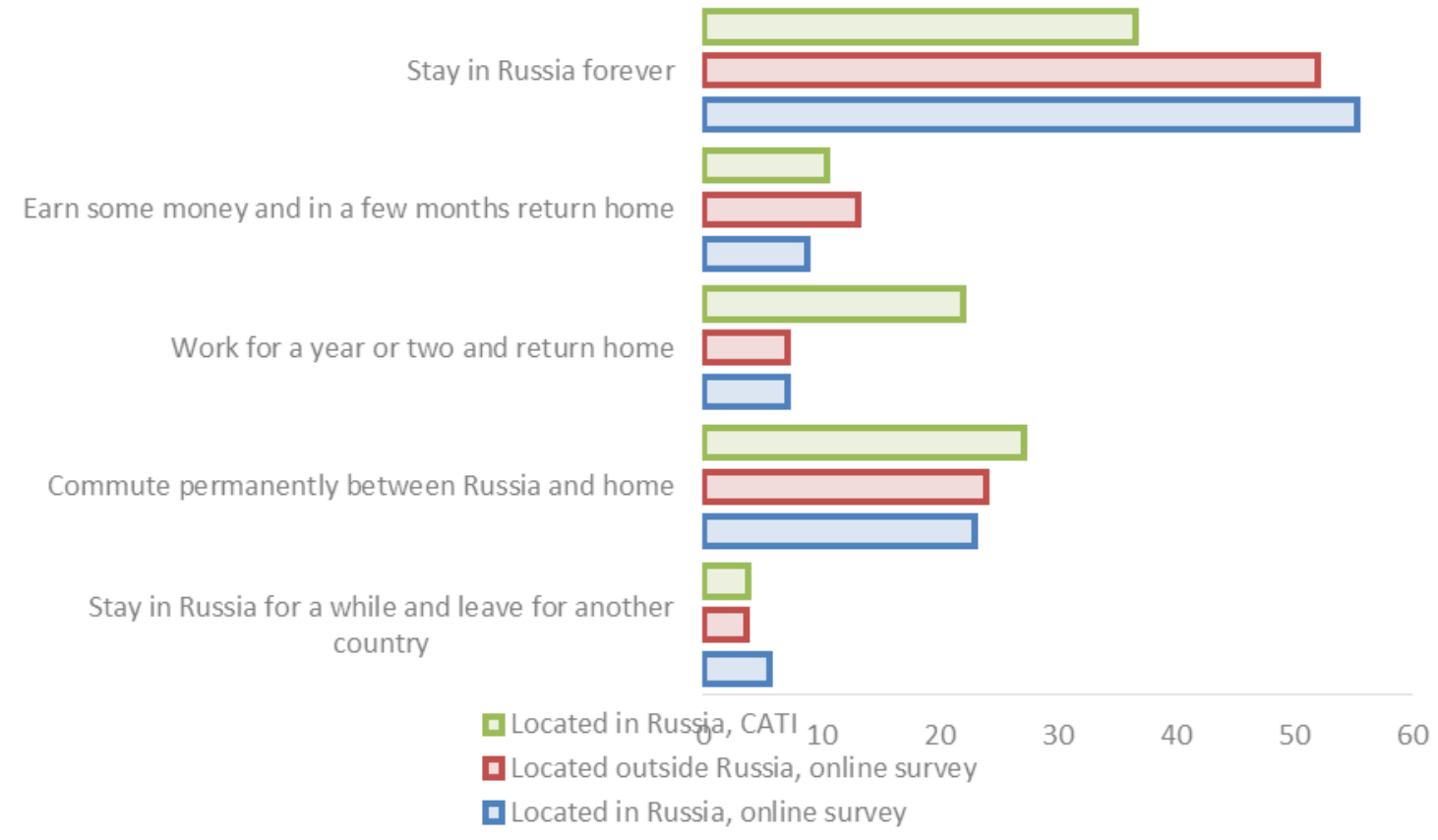

Figure 6. Long-term migration plans of respondents, \% of respondents

If you look at the respondents' plans for their future, more than half of them expressed their intention to eventually stay in Russia forever. Such plans are nothing new to less skilled workers in Central Asia (CATI). It is noteworthy that the largest share of such respondents among those 
outside Russia is among Russians and Azerbaijanis (slightly more than 66\%); the smallest is among Belarusians (22\%).

A desire of a significant part of migrants to integrate is recorded in all surveys. The current hard to predict socio-economic and epidemiological situation in Russia and the sending countries could affect the long-term plans of immigrants from the post-Soviet states and lead to an increase in the number of those who will tend to circular migrations, allowing them to more flexibly respond to the standard of living and the labor market situation in countries of origin and countries of destination. At the same time, the post-pandemic Russian economy will need migrants in the same way as in the pre-pandemic past.

\section{REFERENCES}

Abashin S. (2020). Koronavirus i migratsiya [Coronavirus and migration]. Fond "Liberalnaya missiya", 10.04.2020. (In Russ.) Retrieved from URL:

http://liberal.ru/migration/koronavirus-i-

migraciya?fbclid=IwAR0JowXAmBBiL1QJSK2I5cdbaeLrgp7kvdsxFK6LcEiCD9MwoIVS ZvztYWE

Florinskaya J. (2020). Trudovaya migratsiya v RF na etape zakrytiya granits [Labour migration in the Russian Federation at the stage of border closure]. In V.S.Gurvich, S.M.Drobyshevskiy, A.V.Kolesnikov, V.A.Mau, S.G. Sinelnikov-Murylev (Eds.), Monitoring ekonomicheskoy situatsii v Rossii: tendentsii i vyzovy sotsialno-ekonomicheskogo razvitiya, 17(119), June (pp. 14-19) [Monitoring the economic situation in Russia: trends and challenges of socio-economic development]. Gaidar Institute for Economic Policy, The Russian Presidential Academy of National Economy and Public Administration. (In Russ.) Retrieved from http://www.iep.ru/files/text/crisis_monitoring/2020_7-109_April.pdf

Gimpelson V., Kapelyushnikov R. (2020). Karantinnaya economika i rynok truda [Quarantine economics and labour market. ECONS, 02.06.2020. (In Russ.) Retrieved from https://econs.online/articles/ekonomika/karantinnaya-ekonomika-i-rynok-truda/

GUVM MVD RF, Main Directorate for migration (2020). Statisticheskiye svedeniya po migratsionnoiy situatsii [Statistical data on migration situation]. (In Russ.) (data downloaded 01.09.2020). URL: https://Мвд.pф/Deljatelnost/statistics/migracionnaya

HRW, Human Rights Watch (2020). COVID-19 Fueling Anti-Asian Racism and Xenophobia Worldwide. 12.05.2020. URL: https://www.hrw.org/ru/news/2020/05/12/375044

ILO, International Labor Organization (2020). Protecting migrant workers during the COVID-19 pandemic Recommendations for Policymakers and Constituents. Policy Brief, April. URL: https://www.ilo.org/wcmsp5/groups/public/---ed_protect/---protrav/--migrant/documents/publication/wcms_743268.pdf

Malakhov V.S., Motin A.S. (2020). Vliyanie pandemii COVID-19 na migratsionnyie protsessy i migratsionnuyu politiku v Evropeiskom soyuze i v Rossii [The impact of the COVID-19 pandemic on migration processes and migration policy in the European Union and Russia]. In V.S.Gurvich, S.M.Drobyshevskiy, A.V.Kolesnikov, V.A.Mau, S.G. Sinelnikov-Murylev (Eds.), Monitoring ekonomicheskoy situatsii v Rossii: tendentsii $i$ vyzovy sotsialnoekonomicheskogo razvitiya [Monitoring the economic situation in Russia: trends and challenges of socio-economic development]., 17(119), June (pp.31-42). Gaidar Institute for Economic Policy, The Russian Presidential Academy of National Economy and Public 
Administration. (In Russ.) Retrieved from https://www.ranepa.ru/documents/2020_17119_June.pdf

OECD (2020). Managing international migration under COVID-19. 10.06.2020. URL: https://read.oecd-ilibrary.org/view/?ref=134_134314-9shbokosu5\&title=Managinginternational-migration-under-COVID-19

Pogrebnyak E. (2020). Evraziyskaya integratsiya [Eurasian integration]. Ritm Evrasii, 06.05.2020. (In Russ.). Retrieved from https://www.ritmeurasia.org/news--2020-05-06--vovremja-pandemii-problema-s-migrantami-ne-mogla-ne-obostritsja-48877

Poletaev D. (2020). Migratsionnyye posledstviya «ideal'nogo shtorma»: kakim budet vliyaniye pandemii koronavirusa na problemy migratsii? [Migration Consequences of the "Perfect Storm": What Effect Will the Coronavirus Pandemic Have on Migration Issues?]. RIAC, 07.05.2020. (In Russ.). Retrieved from https://russiancouncil.ru/en/analytics-andcomments/analytics/migration-consequences-of-the-perfect-storm-what-effect-will-thecoronavirus-pandemic-have-on-migrat/?sphrase_id=51028638

Rosstat (2020a). Itogi vyborochnogo nablyudeniya truda migrantov $v 2019$ godu [Results of migrant labour monitoring survey in 2019]. (In Russ.). Retrieved from https://www.gks.ru/itog_inspect

Rosstat (2020b). Sotsialno-economicheskoie polozhenie Rossii: yanvar-aprel 2020 goda [Socialeconomic situation of Russia: April-May 2020]. Moscow: Ministry of Economic Development of Russia. (In Russ.).

Ryazantsev S.V. (2020). Na mezhdunarodnom urovnie nie reshena problema sinkhronizatsii dieystviy [The problem of synchronizing activities has not been solved at the international level]. Nauchnaya Rossia, 17.04.2020. (In Russ.) Retrieved form https://scientificrussia.ru/articles/idesh-v-magazin-a-lyudi-prosto-prosyat-dat-deneg

The World Bank (2020a). COVID-19 Crisis through a Migration Lens. Migration and Development, Brief 32, April. URL: https://www.worldbank.org/en/topic/socialprotection/publication/covid-19-crisis-through-amigration-lens

The World Bank (2020b). Migration and Remittances Data. URL: https://www.worldbank.org/en/topic/migrationremittancesdiasporaissues/brief/migrationremittances-data 